\title{
CD79A Gene
}

National Cancer Institute

\section{Source}

National Cancer Institute. CD79A Gene. NCI Thesaurus. Code C97421.

This gene is involved in B-cell signaling and proliferation. 